\title{
Lumen
}

Selected Proceedings from the Canadian Society for Eighteenth-Century Studies

\section{Communicable Dis-Ease: Wordsworth's Discharged Soldier}

\section{James Allard}

Volume 28, 2009

URI : https://id.erudit.org/iderudit/1012043ar

DOI : https://doi.org/10.7202/1012043ar

Aller au sommaire du numéro

Éditeur(s)

Canadian Society for Eighteenth-Century Studies / Société canadienne d'étude du dix-huitième siècle

ISSN

1209-3696 (imprimé)

1927-8284 (numérique)

Découvrir la revue

Citer cet article

Allard, J. (2009). Communicable Dis-Ease: Wordsworth's Discharged Soldier.

Lumen, 28, 139-150. https://doi.org/10.7202/1012043ar

Copyright (C Canadian Society for Eighteenth-Century Studies / Sociéte canadienne d'étude du dix-huitième siècle, 2009
Ce document est protégé par la loi sur le droit d'auteur. L'utilisation des services d'Érudit (y compris la reproduction) est assujettie à sa politique d'utilisation que vous pouvez consulter en ligne.

https://apropos.erudit.org/fr/usagers/politique-dutilisation/ 


\title{
9: Communicable Dis-Ease: Wordsworth's Discharged Soldier ${ }^{1}$
}

\begin{abstract}
But the duties of the medical man, to whom the charge of those wounded in battle is committed, though less brilliant in the eyes of the world, are often not less dangerous to himself than the exertions of the warrior, nor less deserving of public esteem and reward. The fatigue, anxiety, and disappointments to which he is subjected, can be conceived only by those who have experienced them. The gratitude of his patients is the fruit of his success, and sometimes the reward of his labours; but in meeting with neglect, or ignorant censure, how often is this useful servant of the public obliged to be satisfied with the silent approbation of his own heart, as his only recompense for the utmost endeavours of his skill and humanity. ${ }^{2}$
\end{abstract}

During his 1788 vacation from Cambridge, William Wordsworth had a brief, unremarkable encounter with a solitary figure he first identifies simply as "an uncouth shape," a man "in stature tall, / A foot above man's common measure tall, / And lank, and upright," but who "issued murmuring sounds, as if of pain / Or of uneasy thought.." $\mathrm{A}$ decade later, this encounter would form the basis of the poem known

1 I wish to thank Barbara Seeber, Adriana Pagnotta, and the readers at Lumen for comments on earlier drafts of this paper, and I gratefully acknowledge the financial support of SSHRC and the Humanities Research Institute at Brock University.

2 John Thompson, Report of Observations Made in the British Military Hospitals in Belgium, After the Battle of Waterloo; With Some Remarks Upon Amputation (Edinburgh and London, 1816), 3-4.

3 DS, 38, 41-43, 69-70. Quotations from the poem will be cited by abbreviated title and line number and refer to the MS version edited by Beth Darlington. See Beth Darlington, "Two Early Texts: A Night-Piece and The Discharged Soldier," Bicentenary Wordsworth Studies in Memory of John Alban Finch, ed. Jonathan Wordsworth and Beth Darlington (Ithaca: Cornell University Press, 1970), 425-48. 
as "The Discharged Soldier," which may have been the first piece of Wordsworth's planned-but-never-completed epic The Recluse, later heavily revised and included at the end of Book IV of the 1805 version of The Prelude, and revised again for the published version of that text in 1850. The basic elements of the encounter remain more-or-less the same and likely familiar to many of us: the young poet walks alone until "the road / Presented to [his] view" the shape of a man "clad in military garb, / Though faded yet entire." ${ }^{4}$ As the two begin to talk, prompted by the poet's perhaps sympathetic but still prying curiosity, the man

told a simple fact - that he had gone,

A soldier, to the tropic isles had gone,

Whence he had landed now some ten days past;

That on his landing he had been dismissed,

And with the little strength he yet had left

Was travelling to regain his native home. ${ }^{5}$

During their conversation, the soldier, who has never seemed entirely well, is "by sickness overcome"; the poet helps him to a nearby cottage to "repose / In comfort" and leaves after admonishing the soldier to "not linger in the public ways. ${ }^{\prime 6}$ We actually hear very little about the soldier, even less of his story, and what we do hear comes only from the Wordsworthian narrator, almost never from the soldier's own lips.

This encounter and Wordsworth's writings and re-writings of it have provided ample material for numerous readings of text, poet, and cultural context. In many ways, this "uncouth shape" is yet another example of the many sad, solitary figures that populate Wordsworth's poetry. But aside from deducing simple historical facts about the soldier (Wordsworth's story has him likely serving in the West Indies where, putting down slave revolts, roughly 40,000 troops had died of yellow fever by $1796 ;^{7}$ though he may also serve as a personification of the suffering of soldiers during the then current conflicts with France) critics have made little of the fact that the encounter is with a soldier, one who, in the poet's words, "endured / [...] war, and battle, and the pestilence,"

4 DS, 36-37, 54-55.

5 DS 98-103.

6 DS 151, 154-55, 156.

7 Jonathan Wordsworth, M. H. Abrams, and Stephen Gill, eds., The Prelude: 1799, 1805, 1850 (New York and London: W. W. Norton \& Company, 1979), 148n. 
all of the features of military life abroad. ${ }^{8}$ One such feature that has increasingly attracted scholarly attention is the degree to which soldiers were subject to medical authority: by 1798 , military surgeons were responsible not just for treating injuries and attending to illness but for matters of camp and ship organization, diet, and dress, among many others. ${ }^{9}$ Military medicine was of such growing concern that 1806 saw the creation of the royally sponsored Regius Chair of Military Surgery at the University Edinburgh, instituting military medicine as a discipline unto itself. ${ }^{10}$ An army may travel on its stomach, but only provided that the stomach is intact and functions the way it should. In this environment, those who could maintain the health of that army were becoming increasingly vital to any kind of military effort, central in the lives of every soldier in the services, and at the vanguard of developments in all aspects of medical theory and practice in general.

Using "The Discharged Soldier" episode as a point of access into a broader cultural phenomenon, this essay seeks to examine popular representations of the medical profession in Britain in the late eighteenth and early nineteenth centuries, and to note connections between "domestic" and military medicine and indicate the ways in which such connections further complicate perceptions of the changing role of medicine. These complexities become most evident when we attend to the stories told about, and especially by, those who have been subjected to the authority of medicine. The essay is, inevitably, part of a larger project examining the notion of the "patient narrative": groups of texts which discuss the experiences of being and being made a patient at this pivotal moment in the history of Western medicine. In Wordsworth's soldier, we have one whose subjection to the authority of medicine is made both possible and necessary by the fact that he has been sub-

8 DS, 136-37. Nicholas Roe observes that "the misery of soldiers who were discharged from military service [.. . ] was a widely acknowledged problem," but that even Wordsworth's soldier "appears as the ghostly inhabitant of an alien universe, one who has passed beyond the circumstances where protest, or even compassion might have any effect." See Roe, The Politics of Nature: William Wordsworth and Some Contemporaries (Houndsmills: Palgrave, 2002), 30-31.

9 See, in particular, Alan Bewell, Romanticism and Colonial Disease (Baltimore and London: The Johns Hopkins University Press, 1999), 66-130; and Paul Youngquist, Monstrosities: Bodies and British Romanticism (Minneapolis: University of Minnesota Press, 2003), 161-90.

10 See Matthew H. Kaufman, The Regius Chair of Military Surgery in the University of Edinburgh, 1806-55, The Wellcome Series in the History of Medicine (Amsterdam and New York: Rodopi, 2003). 
jected to the authority of the military. His circumstances call attention to the very notion of "authority" itself, the issue at the heart of the sometimes conflicting contemporary responses to the changing medical profession.

My point here is not to make grand claims concerning the identity, adventures, or specific misfortunes of the soldier himself or to offer a simplistic critique of military and medical institutions, but to attend to the shape and language of the encounter as framed by an awareness of the military medical context of which he would have been a part. In doing so, I operate from two basic premises. First, and somewhat more speculatively, I want to suggest that given the scope and scale of the authority of military medical practitioners of the period, and given the culture of military medicine in general, the soldier would have had numerous encounters with military medicine, regardless of whether he suffered any actual combat injuries or specific camp illnesses. Second, I want to argue that Wordsworth's version of his encounter with the soldier is itself a version of such medical encounters and gives us a sense of both the workings of medical authority and the public perceptions of that authority: the soldier is objectified (subjected to the authority of another), interpreted (read or diagnosed), silenced (the other, in this case the Wordsworthian narrator, speaks for him), and ultimately vanished (as an ill and discharged and thus for all intents and purposes "useless" soldier, his continuing visibility challenges the authority of the institutions that made him). By attending to the admittedly few details of the soldier's story that we do hear, and by noting the ways in which those details are mediated by the narrator's mix of fascination and revulsion, we can begin to form a picture of a time and place that would have seen thousands of such walking ill and wounded return home from various battles and campaigns, each with his own story to tell - stories not just of adventure, battle, and military encounter, but of disease, injury, and medical encounter. I want to argue that both the prescriptiveness of Romantic (military) medical discourse, with its desire to construct and confine the patient within a particular clinical, even disciplinary, discourse, and my critique of it are most manifest when we see how the culture of medicine first establishes a set of discursive practices to create the patient and then sets aside or at the very least revises particular narratives that challenge the authority of this very practice.

As in so many other branches of science, extraordinary medical advances developed within the context of military activity, on the one hand as a matter of simple practical military necessity, and on the other from the availability of bodies in need of a variety of treatments and thus ripe for practice and experimentation. In dedicating a treatise on military surgery to the Duke of York, famed military surgeon George 
Guthrie (the British counterpart to Napoleon's even more famous field surgeon Baron Dominique-Jean Larrey) wrote that

Previously to this period, the Medical Officers of the Army, strictly speaking, had done little towards the improvement of science. The many and important additions made to it, since your Royal Highness extended to them your gracious protections, attest its power; and the benefits which the sick and wounded of the Army have received from their improvement and the amelioration of their situation, must be highly satisfactory to Your Royal Highness. ${ }^{11}$

As the organization of just this one brief passage in a dedication indicates, professional pride, commitment to science, and reverence for authority all seem to come before the importance of any "benefits which the sick and the wounded of the Army have received." These benefits are made to seem like a side-effect of the real work. As numerous scholars have shown (Roy Porter most eloquently), ${ }^{12}$ such at least was often the popular perception of an increasingly powerful and omnipresent medical establishment: as this establishment became more "established" (with the expansion of schools, clinics, and legal statutes), we find developing alongside it a public often awed by but also frequently suspicious of what seemed to be a new clerisy, with access to and mastery of a kind of knowledge not available to those outside of its institutions but to which those on the outside were increasingly beholden. Such familiar texts as William Hogarth's graphic series "The Rewards of Cruelty" and Thomas Hood's poem "Mary's Ghost: A Pathetic Ballad" both depict submission to medical authorities as the final and ultimate punishment for a host of sins. ${ }^{13}$ Locate such growing authority within the already firmly established military institutions, and the com-

11 George J. Guthrie, A Treatise on Gun-Shot Wounds, on Injuries of the Nerves, and on Wounds of the Extremities Requiring the Different Operations of Amputation; [. . . Being a Record of the Opinions and Practice of the Surgical Department of the British Army, at the Termination of the War in Spain, Portugal, and France, in 1814, 2d ed. (London: Burgess and Hill, 1820), iv.

12 There are common themes throughout Porter's enormous body of work, but see especially Roy Porter, The Greatest Benefit to Mankind: A Medical History of Humanity (New York and London: W. W. Norton \& Company, 1997); and Roy Porter, Bodies Politic: Disease, Death and Doctors in Britain, 1650-1900 (Ithaca: Cornell University Press, 2001).

13 James Robert Allard, Romanticism, Medicine, and the Poet's Body, The Nineteenth Century Series (Aldershot, England, and Burlington, Vermont: Ashgate Publishing Company, 2007), 25-26. 
plexities of the relations between the military and "domestic" spheres, between medical institutions and those they serve, even between doctor and patient, seem to multiply and become magnified.

As we would expect, the field of military medicine is vast and varied, and my treatment of it here can only be cursory and tactical. I want to draw attention only to two key points: points that best illustrate the culture of military medicine and how that culture was perceived by the broader public, and that best inform a reading of Wordsworth's text. The first concerns the frequent discussion of the image of the military surgeon. One of the most repeated phrases in the texts I have read places the military surgeon and his staff front and centre in the success of any military campaign, but not necessarily for the reasons we might think: "It is an old remark, and, I fear, not the less true for its antiquity, that more men perish in the regimental practice from the want of proper medical care than by the sword; or, in the words of an ingenious author, 'More die there by the lancet, than by the lance'. ${ }^{\prime 14}$ Such remarks usually serve as the preface to two lines of argument: one, that disease and illness kill more soldiers than do swords and cannons (especially, as Bewell shows, in the tropics), and two, that one bad doctor can do more damage than an entire enemy army. Both lines lead to the conclusion that military surgeons have to be - and, of course, are - virtually god-like.

It comes as no surprise, then, that authors frequently extol the virtues and benefits of a hitch as a military surgeon and sing the praises of those who serve. John Bell's massive three-volume tome The Principles of Surgery opens with a lengthy section on the education and duties of a surgeon, where the author stresses the sense of vocation and commitment to public service that lie at the core of a surgeon's very being. Nowhere, he states, are these traits more evident or more necessary, and nowhere can they be more thoroughly instilled, than in military service:

The situation of a Military Surgeon is more important than that of any other [public servant]; while yet a young man, he has the safety of thousands of committed to him in the most perilous situations, in unhealthy climates, and in the midst of danger. He is to act alone and unassisted, in cases where decision, and perfect knowledge are required; in wounds of the most desperate nature, more various than can be imagined, and to which all parts of the body are equally exposed; his duties, difficult at times, are often to be performed amidst

14 Robert Hamilton, The Duties of a Regimental Surgeon Considered, 2d ed. (London, 1794), vol. 1, 1. 
the hurry, confusion, cries, and horrors of the battle. Even in the seasons of the greatest difficulty, cold and heat, hunger and fatigue, vexation of mind, and all the distresses of foreign service, aggravate disease; and, while they render his exertions of so much importance, teach him imperiously, the necessity of an accurate and ready knowledge of his profession. It is to him that his fellow soldiers look up at the moments of distress: his charities and his friendships are prized beyond all price! What part of education is there, needful or even ornamental, for the Surgeon living at his ease in some richly luxurious city, which the Military Surgeon does not require? What qualifications, of the head, or of the heart? He has no one to consult with in the moment in which the lives of numbers are determined! He has no support but the remembrance of faithful studies, and his inward consciousness of knowledge; nor any thing to encourage him in the many humble yet becoming duties which he has to fulfil, except his own honest principles and good feelings. ${ }^{15}$

Bell then proceeds to tell his reader that all the past and present giants of surgery - including the father of modern scientific surgery, John Hunter, and (naturally) himself - were "bred in this school."16 The stress in the passage is surely on the medical training and experience to be had in the military, but such training is not just in practical matters. The constant reminders that the military surgeon "is to act alone and unassisted" for the care of multitudes in the worst imaginable conditions serve to romanticize him in the minds of the public and in the minds of his fellow surgeons - to the extent that Bell's text becomes as much an exercise in public relations and "spin" as an exhortation to take these lessons seriously. In a passage suggestive of worship Bell writes: "It is to [the surgeon] that his fellow soldiers look up at the moments of distress: his charities and his friendships are prized beyond all price!" Soldiers, especially sick or wounded soldiers almost automatically grant to the surgeon the very authority he is trying to embody; successfully aiding those soldiers solidifies even further the image of the surgeon as absolute authority in matters of health and disease, life and death.

However, the certainty of extensive practical experience (to say nothing of celebrity and ego-boosting) is but one benefit for young surgeons who engage in this crucial service to the State. As the Guthrie passage cited above indicates, military medical service also provided the means and opportunity for scientific advances. Robert Hamilton, in a long 
treatise entitled The Duties of the Regimental Surgeon Considered, encourages the use of soldiers as test cases:

The Surgeon should institute, whenever an opportunity presents, experiments tending to advance the science he is engaged in; none can enjoy better opportunities for the application of new and unusual remedies than army Surgeons. The soldier is entirely at his disposal, as soon as his name is entered on the sick list; by this means he can repeat trials made by others, and put them to the test; or institute new ones, such as may seem to him to promise instruction, and be advantageous to practice. ${ }^{17}$

Famous among such experiments was Navy surgeon James Lind's work on scurvy in 1754, using twelve sailors on board the HMS Salisbury in an experiment that would eventually lead to the Navy's use of lemons, oranges, and, of course, limes, in the diet of its personnel: ${ }^{18}$ two of the sailors got well in less than a week, the others continued sick and the subject of continued experiment, nursed by the two who were well. ${ }^{19}$ Other experiments were conducted on wound infections and diseases such as yellow fever, the particular concern of Wordsworth's soldier. The sheer number of bodies available to the military surgeon, readers are frequently told, can thus benefit all the sciences related to the study and practice of medicine, from discoveries in pharmacology and chemistry to developments in surgical techniques and instruments. And as Hamilton points out, the soldier on the sick list, doubly objectified as soldier and as patient, "is entirely at [the surgeon's] disposal."

Again, I am not suggesting that Wordsworth's soldier served as a uniformed laboratory rat, nor is my goal to condemn or reveal abuses of power in the military; my interest lies in the degree to which soldiers were made to submit to authority - first to the military chain of

17 Robert Hamilton, The Duties of a Regimental Surgeon Considered: With Observations on His General Qualifications; and Hints Relative to a More Respectable Practice, and Better Regulation of That Department, 2d. ed. (London, 1794), vol. 2, 82.

18 Porter, The Greatest Benefit to Mankind, 295.

19 As an interesting side note, and as an insight into Hamilton's tone, the longest chapter in Hamilton's text deals with the surgeon's responsibilities in relation to discipline: the short version is that soldiers can take a lot more punishment than you think, so make sure they are not faking unconsciousness during lashing - enough of a concern, apparently, to prompt not only Hamilton's comments but also Hector Gavin's 1843 On Feigned and Factitious Diseases, which was named, according to the subtitle, Prize Essay in the Class of Military Surgery, in the University of Edinburgh, Session 1835-6. 
command and second (and often much more directly) to the medical men - and in understanding the culture and environment from which Wordsworth's soldier has just emerged, and how aspects of that same culture are re-enacted in the encounter itself. From the beginning of Wordsworth's text, the narrator seems to embody all of the traits of the military surgeon listed by Bell: before his carefully trained and sharply attuned eyes, all is crystal clear; this awareness leaves him "disposed to sympathy," despite "an exhausted mind worn out by toil"; and this sympathy makes possible "A self-possession felt in every pause / And every gentle movement of [his] frame. ${ }^{\prime 20}$ It is in this state of mind that the narrator initially perceives the "uncouth shape" of the soldier. As he silently observes the soldier from a hidden vantage point, the scene becomes what we might consider a diagnostic encounter that reduces the soldier to his disembodied parts:

His legs were long,

So long and shapeless that I looked at them

Forgetful of the body they sustained.

His arms were long and lean, his hands were bare;

His visage, wasted though it seemed, was large

In feature, his cheeks sunken, and his mouth

Showed ghastly in the moonlight[.] $]^{21}$

After (rather unheroically) ensuring that this pathetic being is not a threat, the narrator emerges from his hiding place and engages him in conversation. When asked "his history," the soldier, the poet tells us, "in reply / Was neither slow nor eager; but, unmoved, / And with a quiet uncomplaining voice, / A stately air of mild indifference ${ }^{\prime 22}$ speaks of his service in the tropics and his recent discharge upon arrival back in England. It is especially noteworthy that the narrator pays more attention to the how of the telling than to the what: ${ }^{23}$ though such a focus is entirely in keeping with a text concerned with "the growth of the poet's mind," it is also in keeping with the sense that this is a diagnostic

20 DS, 16, 17, 34-35.

21 DS, 45-51.

22 DS, 94-97.

23 See also C. F. Stone, III, “Narrative Variation in Wordsworth's Versions of 'The Discharged Soldier'," Journal of Narrative Technique 4 (1974): 32-44. 
encounter, that the critical element is the story the narrator will tell of the soldier, not the soldier's story per se.

This motif reappears near the end of the text: "While thus we travelled on I did not fail / To question him of what he had endured / From war, and battle, and the pestilence". ${ }^{24}$ It is clear that Wordsworth had something of a personal interest in the soldier's story: in early 1788 (the time of the encounter), his brother John joined the East India Company and, according the Dorothy Wordsworth, had "set sail for Barbadoes": "I hope," she prays, "poor Lad! that he will be successful and happy, he is much delighted with the profession he has chosen. How we are squandered abroad!" ${ }^{25}$ The lament in that final line, as Bewell thoroughly discusses in another context, is more than a matter of sibling fondness: the tropics were regarded as a massive British graveyard. But more to the point for our present purpose is the narrator's description of how the soldier answers these questions, and the fact we do not get the answers themselves:

He all the while was in demeanour calm,

Concise in answer. Solemn and sublime

He might have seemed, but that in all he said

There was a strange half-absence, and a tone

Of weakness and indifference, as of one

Remembering the importance of his theme

But feeling it no longer. ${ }^{26}$

For the second time in the text, the narrator describes the soldier's story-telling as indifferent, even mechanical, as if only to supply the raw material for someone else to tell the story: in much the same way that a surgeon would read "the text" of a patient's body, speaking unseen illness into existence, and revising the body's story appropriately, so too does the narrator here read the soldier and tell the story the way he wants it told, an act that conceals as much as it reveals, and silences probably more than it speaks. This silencing and revising is further evident in Wordsworth's excessive textual revisions. James Holt McGavran suggests "[ $\mathrm{t}]$ hat the soldier [...] troubled Wordsworth's writing is amply demonstrated in the numerous revisions which occurred as he

25 Ernest De Selincourt, ed., The Letters of William and Dorothy Wordsworth, vol. 1, The Early Years 1787-1805 (Oxford: Oxford University Press, 1967), 16. 
attempted, over and over again, to reduce the unmediated intensity of his earliest drafts to relocate the figure of the soldier within the natural and social order, and thus to maintain personal and textual control." ${ }^{27}$ And the articulation of such control, of such a concern with authority, is precisely what is at stake when we attend, first, to the military medical context from which this figure has recently emerged and second, and perhaps most importantly, to the overlap between that context and domestic space he now occupies.

The encounter itself concludes when the stern, fatherly poet-narrator brings the soldier to the door of the nearby cottage with the promise of food, shelter, and rest. Readers often note the condescension in the narrator's treatment of the soldier here. Matthew Brennan, for example, argues that such an attitude permeates the entire poem: "after all," he writes, "the youth's first reaction to the poor veteran is not sympathy but 'specious cowardise' - he cold-bloodedly gawks at the miserable man as if he were a circus freak; and even when he does act charitably, he does so in a condescending, reproachful way." ${ }^{28}$ But what can be read as condescension can also be read as a response to what we might see as a rupture in the authority of the military-medical dynamic. As he prepares to leave, the narrator "entreated [the soldier]

that henceforth

He would not linger in the public ways

But at the door of cottage or of inn

Demand the succour which his state required,

And told him, feeble as he was, 'twere fit

He asked for relief or alms. ${ }^{29}$

Soldiers returning from the tropics, those who managed to return at all, were often quite ill, if not disfigured, and were in fact often reduced to begging. The sight of so many broken soldiers, like this one still "clad in military garb," must surely have served as a critique of the power of the military and also of the power of medicine, for these were bodies even the god-like military surgeon could not heal; or, worse, bodies which in saving (most frequently via amputation) surgeons had made

27 James Holt McGavran, "Defusing the Discharged Soldier: Wordsworth, Coleridge, and Homosexual Panic," Papers on Language and Literature 32 (1996): 150.

28 Matthew C. Brennan, "The 'ghastly figure moving at my side': The Discharged Soldier as Wordsworth's Shadow," The Wordsworth Circle 18.1 (1987): 19.

29 DS, 155-60. 
visible signs of failure: failure of military power, of medicine, even of Englishness.

In effect, the request that the soldier "not linger in the public ways" is not just a suggestion that he retire for a more private and comfortable respite but a demand that he remain invisible. The apparent disconnect between the poet-narrator's morbid desire to hear the soldier's story and his ostensibly protective impulse to keep the "weakness and indifference" of the "ghastly figure" out of the public ways mimics the complexities of the popular response to the growing authority of the medical establishment: on the one hand, there is a desire to enjoy the benefits of advances made in medical science, but on the other, a suspicion with regard to what sacrifices such advances may have demanded.

In a final act of submission before vanishing, the soldier, "With the same ghastly mildness in his look / [ . . ] said, 'My trust is in the God of Heaven, / And in the eye of him that passes me. ${ }^{\prime 30}$ Wordsworth's discharged soldier, both figure and text, offers a point of access into the ways and means of such acts of submission and into the sometimes brief moments of resistance which sometimes punctuate them.

JAMES ALLARD

Brock University

30 DS, 161-63. 